\title{
The Existence of The Indonesia Peatland Restoration Agency (BRGI) in Perspective of Organization and Authority
}

\author{
Sri Nurhari Susanto, Kadek Cahya Susila Wibawa \\ Faculty of Law, Universitas Diponegoro \\ Prof. Soedarto, SH, Street, Tembalang, Semarang \\ Email: srinurharisusanto@lecturer.undip.ac.id
}

\begin{abstract}
The Indonesia Peatland Restoration Agency (BRGI) is established with the legal basis of Presidential Regulation Number 1 Year 2016. BRGI is founded by coordinating and facilitating peatland restoration in several regions in Indonesia. BRGI is a non-structural institution which is under responsible to the President. BRGI is a state's auxiliary organ (agency or supporting / supporting body). In authority, BRGI can expand its tasks and functions given by the Presidential Regulation or outside the Article 2 and 3 of Presidential Regulation No. 12016. Article 30 section (1) clearly states that BRG conducts the duties for 5 (five) years and ends on December $31^{\text {st }}, 2020$. This is further strengthened by the provision of Article 31 which states that the Presidential Regulation is valid for five years from the enactment. The President with his prerogative has the authority whether to continue the existence of the BRGI or not, even though the Presidential Regulation clearly states the expiration of the institution.
\end{abstract}

Keyword: The Indonesia Peatland Restoration Agency (BRGI), authority, prerogative.

\begin{abstract}
Abstrak
Badan Restorasi Lahan Gambut Indonesia (BRGI) didirikan dengan dasar hukum Peraturan Presiden Nomor 1 Tahun 2016. BRGI didirikan dengan mengoordinasi dan memfasilitasi restorasi lahan gambut di beberapa daerah di Indonesia. BRGI adalah lembaga non-struktural yang bertanggung jawab kepada Presiden. BRGI adalah organ bantu negara (lembaga atau badan pendukung / pendukung). Dalam wewenangnya, BRGI dapat memperluas tugas dan fungsinya yang diberikan oleh Peraturan Presiden atau di luar Pasal 2 dan 3 Peraturan Presiden No. 1 2016. Pasal 30 ayat (1) dengan jelas menyatakan bahwa BRG melaksanakan tugas selama 5 (lima) tahun dan berakhir pada tanggal 31 Desember 2020. Hal ini semakin diperkuat dengan ketentuan Pasal 31 yang menyatakan bahwa Peraturan Presiden ini berlaku selama lima tahun sejak berlakunya. Presiden dengan hak prerogatifnya memiliki wewenang apakah akan melanjutkan keberadaan BRGI atau tidak, meskipun Peraturan Presiden dengan jelas menyatakan berakhirnya lembaga.
\end{abstract}

Kata kunci: Badan Restorasi Lahan Gambut Indonesia (BRGI), otoritas, hak prerogatif. 


\section{Administrative Law \& Governance Journal. Volume 2 Issue 1, March 2020 ISSN. 2621-2781 Online}

\section{A. Introduction}

A state/country as an organization has equipment to realize the goals and desires of the country (staatswill). ${ }^{1}$ the concept of state institution terminologically has a variety of terms, as in the English literature, as state institutions use the term "political institution", Dutch literature is known as "staat organen", while Indonesian literature uses the term "lembaga negara, badan negara, atau organ negara". ${ }^{2}$

Based on Montesquieu doctrine, State institutions are idealized consisting of only three main institutions for the implementation of state power, which are: parliament, government, and court which reflect legislative, executive and judicial functions. However, since entering the $19^{\text {th }}$ century, with the emergence of demands for the state to take a greater role in the dynamics of social and state life, the number of state institutions has also increased, in accordance with the demands of the needs according to the welfare state doctrine.

In the development of history, the theory and idea about the organization of power and state organization have a very rapid development phase. This is due to the demands of real conditions and needs, either in social, economic, political and cultural factors in the midst of an increasingly complex wave of globalism versus localism. It causes variations in the structure and function of organizations and state institutions to develop, both in many varieties and the shape. Thus, based on Jimly Asshiddique ${ }^{3}$, a country conducts institutional experimentation through various forms of government organs which are considered more effective and efficient so that public services can be truly guaranteed. This institution is called by the terms of council, commission, committee, board or authority.

Hans Kelsen in understanding the definition of organ and state institutions, states: "Whoever fulfills a function determined by the legal order is an organ. These functions, be they of a norm creating or of a norm applying character, are all ultimately

Hendra Nurtjahjo, "Lembaga, Badan, Dan Komisi Negara Independen (State Auxiliary Agencies) Di Indonesia: Tinjauan Hukum Tata Negara," Jurnal Hukum \& Pembangunan 35, No. 3 (2017): 275, https://doi.org/10.21143/jhp.vol35.no3.1518.

2 Firmansyah Arifin dkk., Lembaga Negara Dan Sengketa Kewenangan Antarlembaga Negara (Jakarta: KRHN bekerjasama dengan MKRI didukung oleh The Asia Foundation dan USAID, 2005).

3 Jimly Asshiddiqie, Perkembangan Dan Konsolidasi Lembaga Negara Pasca Reformasi (Jakarta: Sekretariat Jenderal dan Kepaniteraan Mahkamah Konstitusi RI, 2006), http://mitrahukum.org/wpcontent/uploads/2012/09/PERKEMBANGAN_DAN_KONSOLIDASI.pdf. 
aimed at the execution of a legal sanction". ${ }^{4}$ It means that state's organ is not always organic. besides organic organs, more broadly, each position determined by law can also be called an organ, as long as its functions are norm creating and/or norm applying.

According to Jimly Asshidiqie ${ }^{5}$, the concept of state's organ and State institutions have broad meaning. Thus, they can't be narrowed to the understanding of the three branches of legislative, executive and judicial power. The concept or understanding of state's organs and state institutions according to him are as follow:

1. In broad meaning, state institution consists each individual who fulfills the function of law creating and law applying.

2. State's organ in the broadest sense but narrower than the first sense, includes each individual who carries out the function of creating law and applying and also has a position as or in the structure of state positions or government positions.

3. State's organ in narrower meaning is agency or organization that carries out the functions of law creating and/or law applying within the framework of the structure and system of the state or government. In this meaning, state institution includes the definition of state institutions formed based on Constitution of the Republic of Indonesia (UUD), Law (UU), Presidential Regulation or by decisions of a lower level, both at the central or regional level.

4. State's organ in narrower meaning is state's organ or institutions only limited to the understanding of state institutions which are formed based on the constitution, laws, or by lower regulations.

5. Besides, the four meaning above are to give specificity to state institutions at the central level whose formation is regulated and determined by the 1945 Constitution, such as Presidential institutions (President and Vice President), MPR/People's Consultative Assembly, DPR/People's Representative Council, DPD/Regional Representative Council of Indonesia, MA/Supreme Court of Indonesia, MK/Constitutional Court, and BPK/The Audit Board can also be referred to as state separate institutions because of its high position. These constitutional institutions want to be called as a high state institution can also be accepted.

Hans Kelsen, General Theory of Law and State (New York: Russell \& Russell, 1961), p. 192.

Asshiddiqie, Perkembangan Dan Konsolidasi Lembaga Negara Pasca Reformasi, p.35-36. 


\section{Administrative Law \& Governance Journal. Volume 2 Issue 1, March 2020| ISSN. 2621-2781 Online}

All constitutional institutions are considered equal and only distinguished from differences in their respective functions and authorities. These seven high state institutions can be associated to the understanding of the main state equipment (main organs).

The Indonesia Peatland Restoration Agency (BRGI) is an state's organ whose existence is established based on Presidential Regulation Number 1 Year 2016. based on the consideration letter a of Presidential Regulation Number 1 Year 2016, that the BRGI is established with the intention to accelerate the restoration of the area and restore the hydrological function of peat due to forest and land fires specifically, systematically, directed, integrated and comprehensive. It means that the purpose of the development of BRGI is to handle the acceleration of the restoration of the area and restore the hydrological function of peatland due to forest fires effectively and efficiently. Moreover, Article 30 paragraph (1) of Presidential Decree Number 1 of 2016 stated that BRGI performs its duties for five years and will expire on December 31, 2020. It is reiterated in Article 31 which states that the Presidential Decree is effective from the date of promulgation and valid for five years.

Problems arise relating to the organization (institutions and human resources) of BRGI and its duties, the authority attached to it. Based on this background, the problem raised in this paper is how the position of the Indonesia Peatland Restoration Agency (BRGI) will be seen from an institutional and authority perspectives after the enactment of Presidential Decree Number 1 of 2016 ?

\section{B. Discussion}

1. The Institutional Perspective of Indonesia Peatland Restoration Agency (BRGI) Based on the Presidential Decree Number 1 of 2016

Since the reformation wave in 1998, the UUDNRI 1945 has amended 4 (four) times. One of the consequences of these amendments is the emergence of state auxiliary bodies/agencies/organs, which become the new face of state administration in Indonesia. It can serve as part of the application of the principle of sharing of power. The term "states auxiliary bodies/agencies/organs" is paired with serving, assisting, auxiliaries, and supporting state institutions. The term is given as a differentiator from the main state institutions (main organs). 


\section{Administrative Law \& Governance Journal. Volume 2 Issue 1, March 2020| ISSN. 2621-2781 Online}

The principle of sharing of power in its application is based on 2 (two) considerations, including: For efficiency, there is a need to institutionalize to integrate various functions into a single unit into a mixed function. The need to prevent particular power functions is free from political intervention and conflicts of interest. Based on these reasons, since the end of the $20^{\text {th }}$ century to the beginning of the $21^{\text {st }}$ century, many new institutions have emerged outside the common organizational structure of government.

Besides being the need to complete duties fast, the formation of states auxiliary bodies/agencies/organs also shows the ineffectiveness and efficiency of ministries and LPNK (Non-Ministry Government Institutions). Moreover, the formation can also be caused by a lack of trust in existing institutions which leads to the formation of a new institution. The formation of state institutions/agencies/commissions has different legal bases that can be based on the Constitution (UUD), Laws, Presidential Decree (Perpres), and those formed because of international obligations.

According to John Alder, some institutions are called public corporations (nationalized industries), while others called Quangos (quasi-autonomous nongovernment bodies). However, generally, Alder referred to as Non-department bodies, public agencies, commissions, boards, and authorities. ${ }^{6}$ In general, these institutions serve as a quasi-governmental world of appointed bodies and are non-departmental agencies, single-purpose authorities (have authority for a single purpose), and mixed public-private institutions (a mixture of public and private institutions). It is quasi or semi-governmental, and is given a single or sometimes a mixed-function such as on the one hand as a regulator, but also punishes like the punisher like the judiciary which is mixed with the legislature. ${ }^{7}$ Therefore, besides called as auxiliary state's organs, these institutions also called selfregulatory agencies, independent supervisory bodies, or institutions that perform mix functions ${ }^{8}$.

In addressing these functions, some experts are classified within the scope of executive power, and also categorized into new power groups, which is the fourth power (the fourth branch of the government-fourth branch of government), as stated by Yves

John Alder, Constitutions and Administrative Law (London: The Macmillan Press LTD, 1989), p. 232.

Jimly Asshiddiqie,"Struktur Ketatanegaraan Indonesia Setelah Perubahan Keempat UUD Tahun 1945" (Denpasar, 2003), p. 6.

Asshiddiqie, p. 7. 


\section{Administrative Law \& Governance Journal. Volume 2 Issue 1, March 2020| ISSN. 2621-2781 Online}

Meny and Andrew Knapp as follows ${ }^{9}$ : Regulatory and monitoring bodies are a new type of autonomous administration which has been most widely developed in the United States (where it is sometimes referred to as the "headless fourth branch" of the government). It takes the form of what is generally known as Independent Regulatory Commissions.

Referring to the provisions of Article 1 paragraph (1) of Presidential Decree No.1 of 2016 concerning the Peatland Restoration Agency which formulates: "The Peatland Restoration Agency is a non-structural institution under and is responsible to the President", then it can be seen that institutionally, BRGI as Non-structural institution is a "state's auxiliary bodies/agencies/organs" (assisting/auxiliary institution) and is not the main institution (main organ) in the constitutional system.

The key reasons underlying the emergence of assisting/auxiliary institution that is independent are: first, sociological reasons due to the increasingly complex development of (modern) state activities, which requires many institutions or equipment required to perform the duties or functions of the state. Equipment or state institutions resulted from the constitution are no longer able to accommodate specific tasks that need independence and professionalism in their implementation in general. The consequence demanded is to form a new institution which becomes conditio sine qua non (logical consequence) for the country's growth and development in holding the aspirations and dynamics of modern society. Second, administrative reasons which are more caused by the demand for effective, efficient, and fair governance. The implementation of one function or one task does not always have to be located in one institutional organ, especially when the functions that become the task of the institution do not run effectively and efficiently.

It was then stated that BRGI is under and accountable to the president, indicating that in performing its duties and functions, BRGI gave its responsibilities to the President through the Minister in charge of government affairs associated with the duties and functions performed by BRGI (Minister of Environment and Forestry-vide Article 19 of Presidential Decree No.1 of 2016). Minister is a political position that has a significant public position in the government.

9 Yves Meny dan Andrew Knapp, Government and Politic in Western Europe: Britain, France, Italy, Germany, 3rd ed. (Oxford: Oxford University Press, 1998), p. 281. 


\section{Administrative Law \& Governance Journal. Volume 2 Issue 1, March 2020| ISSN. 2621-2781 Online}

Furthermore, the provisions of Article 20 of Presidential Decree No.1 of 2016 formulated that "The implementation of BRGI's duties and functions is evaluated by the Minister who organizes government affairs in the field of environment and forestry, the minister who performs government affairs in the field of the state apparatus, and the Head of the Presidential Staff Office". The word "evaluated" in the formulation of Article 20, institutionally "does not mean" that the position of BRGI is lower than the institution that evaluates it.

Jimly Asshiddiqie ${ }^{10}$ explained that: The issue of the constitutionality of state institutions is not always associated with the degree of higher or lower hierarchy between institutions in constitutional position. The relevant issue is "what and how the Constitution (UUD) regulates and determines matters related to the state institution.

Although the position is lower than the common constitutional institution, = as long as the provisions regarding the relevant institution are regulated in the Constitution, it means that the institution is associated with/related to the issue of constitutionality.

The achievement of the objectives of the state's goal as a national goal shows increasingly complex additions, and it cannot be achieved only with the main state's organs. Therefore, the auxiliary state's organs are formed with the function of serving. One of them is the Peatland Restoration Agency which is incorporated in legal products in the form of a Presidential Decree.

\section{The Authority Perspective of Indonesia Peatland Restoration Agency (BRGI) Based} on the Presidential Decree Number 1 of 2016

In a (public or private) organization, authority always runs in parallel with tasks and functions. An organization performs functions in carrying out the main tasks. Function means something that contains uses or advantages. The function of a formal institution or body is the existence of power in the form of rights and duties possessed by a person in his position in the organization to perform something in line with their respective fields of duty. The function of the institution or body is arranged as a guide or direction for the organization in performing activities and achieving the objectives of the organization.

\footnotetext{
10 Asshiddiqie, "Struktur Ketatanegaraan Indonesia Setelah Perubahan Keempat UUD Tahun 1945", p. 48.
} 
A task is an obligation that must be performed, work that becomes a responsibility, an order to do or conduct something to achieve a goal. The task as a unit of work or the most essential and regular activities carried out by individuals in an organization that gives an overview of the scope or complexity of the position or organization to achieve certain goals. $^{11}$

Task and function are closely associated with authority, which is the ability to perform a public legal action, or legally, the authority is the ability to act given by the applicable laws and regulations and conduct legal relations. Organizationally, authority is a juridical ability based on public law. ${ }^{12}$ Kadek Wibawa explained that: ${ }^{13}$

Generally, the government carries out three main functions that are based on public authority (bestuurs bevoegdheid): carrying out normative or legitimate functions (legitimerende functie), instrumental functions (instrumentele functie), and a guarantee or protection function (waarborg functie).

It is always bound to rights and obligations (rechten en plichten), so that authority is not merely interpreted as a right under public law, but also an obligation based on public law. It is not only interpreted as power. Hence, in running rights based on public law, it is always bound by obligations based on public law (which is not written or general principles of good governance).

In this case, authority can be divided into: ${ }^{14}$ Granting authority: granting rights to, and assigning obligations to the body (attribution/mandate). Implementation of authority: perform public rights and obligations which means preparing and making decisions. Legal consequences of the implementation of authority: all rights and/or obligations that lie with the people/burger, people's groups, and bodies.

In terms of attribution, the recipient of the authority can construct new authority or expand the existing authority, with internal and external responsibilities, the implementation of authority is fully attributed to the recipient of the authority (atributaris). ${ }^{15}$ The provisions

\footnotetext{
Muammar Himawan, Pokok-Pokok Organisasi Modern (Jakarta: Bina Ilmu, 2004), p. 38.

Prajudi Admosudirjo, Teori Kewenangan (Jakarta: PT. Rineka Cipta, 2001), p. 4.

Kadek Cahya Susila Wibawa, "Menakar Kewenangan Dan Tanggung Jawab Pejabat Pembuat Akta Tanah (PPAT) Dalam Perspektif Bestuurs Bevoegdheid," Crepido 01, no. 01 (2019): 40-51, https://ejournal2.undip.ac.id/index.php/crepido/article/view/6327, p.44.

14 Prajudi Admosudirjo, p. 7.

15 Ridwan HR, Hukum Admiistrasi Negara, Revisi (Jakarta: PT RajaGrafindo Persada, 2011), p. 105.
} 
of Article 29 of Presidential Decree No. 1 of 2016 have shown this by formulating that "Details on the duties, functions, organizational structure, and mechanism of implementing BRGI tasks are further regulated by the Head". According to the provisions of Article 29 of Presidential Decree No.1 of 2016, the Head of BRGI is given the authority to expand the tasks, functions, organizational structure, and mechanism of implementation of BRGI's tasks according to needs, as stipulated in the provisions of Article 2 (tasks), Article 3 (functions), Article 5 (organizational structure), as well as the mechanism for performing the tasks carried out by the secretariat and deputies. BRGI's authority in coordinating tasks and facilitating peatland restoration (Article 2), in its implementation, the Head of BRGI must demonstrate an "active role" both internally (in BRGI) and externally (in relevant Ministries and related institution-vide Article 13 and partners, both national or foreign partners).

\section{The Existence of the Indonesia Peatland Restoration Agency (BRGI) After the Non}

\section{Enforceable Presidential Decree Number 1 of 2016 On December 31, 2020}

The difference between the main and auxiliary institutions is that the main institution is a permanent one, while the assisting/auxiliary state institution can grow, develop, and possibly be removed, depending on the conditions. ${ }^{16}$ Concerning the provisions contained in Presidential Decree No.1 of 2016, the provisions of Article 30 imply that matter. Article 30 of Presidential Decree No.1 of 2016 formulates that: 1). BRGI performs its duties for 5 (five) years and ends on December 31, 2020. 2). After the end of the term of BRGI as stated in paragraph (1), BRGI activities become the responsibility of the Minister who performs government affairs in the environmental and forestry fields.

According to the formulation of the provisions of Article 30 paragraph (1), the presence of this institution/body in performing its tasks is only limited for 5 (five) years. Although normatively BRGI is only given the tasks for 5 years, the end and sustainability of this institution depend on the president's "prerogative" in examining the existence of BRGI. The prerogative as according to the Indonesian Dictionary is defined as the

16 Sri Soemantri, "Lembaga Negara Dan State Auxiliary Bodies Dalam Sistem Ketatanegaraan Menurut UUD 1945", Disampaikan dalam dialog hukum dan non hukum "Penataan State Auxiliary Bodies dalam Sistem Ketatanegaraan" Departemen Hukum dan HAM RI, Badan Pembinaan Hukum Nasional bekerjasama dengan Fakultas Hukum Universitas Airlangga (Surabaya, 2009). 


\section{Administrative Law \& Governance Journal. Volume 2 Issue 1, March 2020| ISSN. 2621-2781 Online}

privilege of the head of state regarding laws and constitutions outside the powers of representative bodies.

The granting of the prerogative rights to carry out certain matters for the President is a consequence of followers of the understanding of the welfare state law. In the insight into the rule of material law, the functions and tasks of the government are extended broadly that they no longer merely perform the constitution an sich, but rather perform things according to their creations and authorities. The primary task of the government in this material law state is to build community welfare, and thus, it is given/created an authority called the freies Ermessen (Discretionary power, Discretion), which is an authority for the government to intervene or interpose in various community activities to establish the welfare of the community. Hence, the government in this material law state is required to be active.

As long as the rights possessed by the president are constitutional, then they are part of the executive power of the president. Any rights owned constitutionally by the president are executive rights which are also prerogative rights, even though the explanation of what is called the president's prerogative rights does not exist.

In material law countries, freies Ermessen/Discretionary power/discretion have implications for the government both in the executive and legislative fields. In the field of legislation, it can be noted that there are three types of authority for the government, including the authority of the initiative (creating regulations equivalent to the constitution without having to ask for parliamentary approval on the condition that the regulation is made because of forced conditions); delegation authority (creating regulation of implementation on the provisions of the constitution); and the droit function (making his/her interpretations for regulatory material). In the field of government, the implications of freies Ermessen are marked by prerogative rights. ${ }^{17}$

Therefore, the amount of portion to hold the prerogative for the government will be highly determined by how deep the adherence to the rule of law perspective. It means that in a country that tends to adhere to a material law state, its portion of prerogative rights will be greater than that of a country that tends to have an insight into the formal rule of law state. The presence of a prerogative in the constitution does not matter, depending on

17 Moh. Mahfud MD, Hukum Dan Pilar-Pilar Demokrasi (Yogyakarta: Gama Media, 1999), p. 258. 


\section{Administrative Law \& Governance Journal. Volume 2 Issue 1, March 2020 ISSN. 2621-2781 Online}

the way it is interpreted. Because prerogative right exists when the President has the right to perform something without asking for the approval of another person or institution. Bagir Manan stated some characteristics of prerogative power, including: ${ }^{18}$ a. As "residual power"; b. Represents the power of discretion (freies Ermessen, Beleid); c. Not in written law; $d$. The use is restricted; e. Will be removed when it is regulated in law or the Constitution.

Related to the continued existence of BRGI in the future, it must be able to demonstrate good performance effectively, efficiently, and fairly. In indicates that BRGI should be able to convince the President in performing the tasks given by the President, as well as meeting the President's expectations so that the President with his prerogative rights can extend it for the next 5 (five) years by amending Presidential Decree No.1 of 2016. BRGI also needs to ask for support from the regional and village governments where peatland restoration is performed, elucidating to the President about integrating the peatland restoration program into regional and village development programs, asking international support, partners, NGOs, and universities.

\section{Conclusion}

Based on the above elucidation, the following conclusions can be drawn: BRGI as state's auxiliary orga $n$ becomes "savior" institution/body, which performs the noble task of restoring millions of hectares of peatland damage that spread from Sabang to Merauke. Its existence is determined by the degree of need (situation and conditions). Institutionally, it has become a strategic body to save critical (damaged) peatlands.

The formation of the BRGI becomes the president's prerogative which, with consideration of efficiency and effectiveness, is assigned to assist/support the performed by the relevant ministries and local governments in handling the critical situation of peatlands. In terms of authority, BRGI can expand its tasks and functions given by the Presidential Decree No.1 of 2016. Normatively, the existence of BRGI will end on December 31, 2020; however politically and sociologically, the President has the prerogative to extend the presence of BRGI as long as it shows fine performance in an

18 Bagir Manan, “Kekuasaan Prerogatif,” (Bandung, 1998), p. 6. 
effective, efficient, and fair manner and the President is pleased to extend the existence of the BRGI.

\section{References}

Alder, John. Constitutions and Administrative Law. London: The Macmillan Press LTD, 1989. Asshiddiqie, Jimly. Perkembangan Dan Konsolidasi Lembaga Negara Pasca Reformasi. Jakarta: Sekretariat Jenderal dan Kepaniteraan Mahkamah Konstitusi RI, 2006. http://mitrahukum.org/wpcontent/uploads/2012/09/PERKEMBANGAN_DAN_KONSOLIDASI.pdf.

Asshiddiqie, Jimly. "Struktur Ketatanegaraan Indonesia Setelah Perubahan Keempat UUD Tahun 1945.” Denpasar, 2003.

Cahya, Kadek, and Susila Wibawa. "Menakar Kewenangan Dan Tanggung Jawab Pejabat Pembuat Akta Tanah ( Ppat ) Dalam Perspektif Bestuurs Bevoegdheid.” Crepido 01, no. 01 (2019): 40-51. https://ejournal2.undip.ac.id/index.php/crepido/article/view/6327.

Firmansyah Arifin dkk. Lembaga Negara Dan Sengketa Kewenangan Antarlembaga Negara.

Jakarta: KRHN bekerjasama dengan MKRI didukung oleh The Asia Foundation dan USAID, 2005.

Himawan, Muammar. Pokok-Pokok Organisasi Modern. Jakarta: Bina Ilmu, 2004.

HR, Ridwan. Hukum Admiistrasi Negara. Revisi. Jakarta: PT RajaGrafindo Persada, 2011.

Kelsen, Hans. General Theory of Law and State. New York: Russell \& Russell, 1961.

Knapp, Yves Meny dan Andrew. Government and Politic in Western Europe: Britain, France, Italy, Germany. 3rd ed. Oxford: Oxford University Press, 1998.

Manan, Bagir. "Kekuasaan Prerogatif,.” Bandung, 1998.

MD, Moh. Mahfud. Hukum Dan Pilar-Pilar Demokrasi. Yogyakarta: Gama Media, 1999.

Nurtjahjo, Hendra. "Lembaga, Badan, Dan Komisi Negara Independen (State Auxiliary Agencies) Di Indonesia: Tinjauan Hukum Tata Negara.” Jurnal Hukum \& Pembangunan 35, no. 3 (2017): 275. https://doi.org/10.21143/jhp.vol35.no3.1518.

Prajudi Admosudirjo. Teori Kewenangan. Jakarta: PT. Rineka Cipta, 2001.

Soemantri, Sri. "Lembaga Negara Dan State Auxiliary Bodies Dalam Sistem Ketatanegaraan Menurut UUD 1945." Surabaya, 2009. 